University of Nebraska - Lincoln

DigitalCommons@University of Nebraska - Lincoln

Development of Hydrotaea aenescens (Diptera: Muscidae) in Manure of Unweaned Dairy Calves and Lactating Cows

\author{
Jerome Hogsette \\ USDA-ARS, Jerry.Hogsette@ars.usda.gov \\ Robert Farkas \\ Szent Istvan University \\ Reginald Coler \\ University of Massachusetts - Amherst
}

Follow this and additional works at: https://digitalcommons.unl.edu/usdaarsfacpub

Part of the Agricultural Science Commons

Hogsette, Jerome; Farkas, Robert; and Coler, Reginald, "Development of Hydrotaea aenescens (Diptera: Muscidae) in Manure of Unweaned Dairy Calves and Lactating Cows" (2002). Publications from USDAARS / UNL Faculty. 1013.

https://digitalcommons.unl.edu/usdaarsfacpub/1013

This Article is brought to you for free and open access by the U.S. Department of Agriculture: Agricultural Research Service, Lincoln, Nebraska at DigitalCommons@University of Nebraska - Lincoln. It has been accepted for inclusion in Publications from USDA-ARS / UNL Faculty by an authorized administrator of DigitalCommons@University of Nebraska - Lincoln. 


\title{
Development of Hydrotaea aenescens (Diptera: Muscidae) in Manure of Unweaned Dairy Calves and Lactating Cows
}

\author{
JEROME A. HOGSETTE, RÓBERT FARKAS, ${ }^{1}$ and REGINALD R. COLER ${ }^{2}$ \\ Center for Medical, Agricultural, and Veterinary Entomology, USDA-ARS, P.O. Box 14565, \\ Gainesville, FL 32604
}

\begin{abstract}
J. Econ. Entomol. 95(2): 527-530 (2002)
ABSTRACT In laboratory studies performed in the United States and Hungary, the dump fly Hydrotaea aenescens (Wiedemann) was reared successfully in manure of 1- to 8-wk-old dairy calves, and in manure from adult lactating dairy cows. Survival in manure collected from 1-wk-old calves was poor $(7.2 \%)$, better in manure collected from 2 - and 3-wk-old calves (53.5\%), and best in manure collected from 4 - to 8 -wk-old calves (71.4\%). Survival in cow manure was slightly lower $(47.4 \%)$ than that in calf manure. Reasons for different rates of development in the United States and in Hungary, and by calf age are discussed as are implications for biological control.
\end{abstract}

KEY WORDS Hydrotaea aenescens, house fly, calf manure, cow manure, biological control

LARVAE OF THE dump fly Hydrotaea aenescens (Wiedemann) (formerly Ophyra aenescens) are facultative predators that can kill $\approx 15-20$ house fly, Musca domestica L., larvae daily (Hogsette 1979, Geden et al. 1988, Farkas and Jantyik 1990, Farkas and Papp 1990). Large numbers of adults can be found in dark areas of animal confinement buildings (Nolan and Kissam 1987), but they seem disinterested in animals or farm workers, and are a nuisance to neither (Müller et al. 1981, Betke et al. 1989).

Hydrotaea aenescens was associated with dumps and garbage (Stein et al. 1977) when the fly was first observed in Germany (Sick 1971). However, in agricultural situations, the fly has been observed on swine (Robertson and Sanders 1979), dairy (J.A.H., unpublished data) and poultry farms (Farkas and Papp 1990), and in habitats such as spilled feed and silage (J.A.H. unpublished data). Hydrotaea aenescens has been used successfully for management of house fly populations on swine and poultry farms in the United States and Europe (Betke et al. 1989, Ruszler 1989, Turner and Carter 1990, Jespersen 1994, Hogsette and Jacobs 1999), and studies have verified the capability of $H$. aenescens to develop in swine and poultry manures having a wide moisture range (Farkas et al. 1998).

Despite the successful application of H. aenescens in fly management programs on swine and poultry farms, we are unaware of any similar applications, successful or otherwise, on cattle farms, either beef or dairy. As

\footnotetext{
${ }^{1}$ Szent István University, Faculty of Veterinary Science, Department of Parasitology and Zoology, H-1400 Budapest, Pf. 2, Hungary.

${ }^{2} 102$ Fernald Hall, 270 Stockbridge Road, University of Massachusetts, Amherst, MA 01003.
}

stated above, $H$. aenescens adults have been observed on dairies, and $H$. aenescens larvae have been found in grain and silage substrates (J.A.H., unpublished data). However, we have rarely if ever observed $H$. aenescens larvae in the manure of dairy cattle. Although $\mathrm{H}$. aenescens has been observed breeding around piles of cattle manure (Axtell 1986), we are not aware of published reports describing the development of $H$. aenescens in this substrate. Could there be unknown factors that limit development of $H$. aenescens larvae in ruminant manures? On dairies, calf weaning areas are a major source of fly production (Miller 1993); but until fully weaned, calves are essentially nonruminant animals producing nonruminant manure.

The purpose of our study was to determine the ability of $H$. aenescens to develop in the manure of dairy calves during the 8-wk weaning period, and for comparison, the manure of mature, lactating dairy cows. Positive results would provide an incentive for development of $H$. aenescens as another nonchemical alternative for fly control on dairies.

\section{Materials and Methods}

Fly Strains. The laboratory strains of $H$. aenescens were colonized in 1989 from adults collected on a caged-layer poultry farm near Budapest, Hungary, and from adults collected on a caged-layer poultry farm near Dover, Hillsborough County, FL. Adults of both strains were kept in screened cages under standard laboratory conditions $\left(26 \pm 2^{\circ} \mathrm{C}, 60 \pm 5 \% \mathrm{RH}\right.$, a photoperiod of 12:12 [L:D] h.) and given ad libitum access to water, and one of the following dry adult diets: powdered milk, granulated sugar, and powdered egg yolk (6:6:1) (Gainesville) (Hogsette and Koehler 
Table 1. Mean \pm SE numbers of pupae and adults and mean \pm SE pupal weights of $H$. aenescens produced in manure collected from dairy calves aged 1-8 wk and lactating dairy cows in Budapest, Hungary, and Gainesville, Florida, USA

\begin{tabular}{|c|c|c|c|c|c|c|}
\hline \multirow{2}{*}{ Medium/Manure } & \multicolumn{2}{|c|}{ No. of pupae } & \multicolumn{2}{|c|}{ Weight of pupae, mg } & \multicolumn{2}{|c|}{ No. of adults } \\
\hline & Budapest & Gainesville & Budapest & Gainesville & Budapest & Gainesville \\
\hline Control & $45.8(0.8) \mathrm{a}$ & $45.8(1.5) \mathrm{a}$ & - & $17.0(0.3) \mathrm{a}$ & $40.7(1.2) \mathrm{a}$ & $44.2(1.6) \mathrm{b}$ \\
\hline Week 1 manure & $0.5(0.3) \mathrm{c}$ & $14.2(5.9) \mathrm{d}$ & $4.0(2.6) \mathrm{b}$ & $16.1(0.5) \mathrm{a}$ & $0.5(0.3) \mathrm{c}$ & $6.7(3.0) \mathrm{d}$ \\
\hline Week 2 manure & $6.7(1.8) \mathrm{c}$ & $49.0(0.8) \mathrm{a}$ & $14.3(0.5) \mathrm{a}$ & $16.8(0.1) \mathrm{a}$ & $5.7(1.6) \mathrm{c}$ & $46.2(0.8) \mathrm{a}$ \\
\hline Week 3 manure & $9.0(1.1) \mathrm{c}$ & $49.5(0.5) \mathrm{a}$ & $16.2(0.3) \mathrm{a}$ & $16.1(0.5) \mathrm{a}$ & $7.7(1.3) \mathrm{c}$ & $47.5(0.7) \mathrm{a}$ \\
\hline Week 4 manure & $37.2(1.6) \mathrm{b}$ & $42.5(2.8) \mathrm{a}$ & $17.4(0.2) \mathrm{a}$ & $17.4(0.2) \mathrm{a}$ & $35.5(1.9) \mathrm{a}$ & $39.7(2.6) \mathrm{b}$ \\
\hline Week 5 manure & $34.3(2.7) \mathrm{b}$ & $47.2(1.2) \mathrm{a}$ & $17.6(0.2) \mathrm{a}$ & $17.4(0.3) \mathrm{a}$ & $31.8(3.0) \mathrm{a}$ & $42.2(0.9) \mathrm{b}$ \\
\hline Week 6 manure & $31.0(3.9) \mathrm{b}$ & $42.5(2.1) \mathrm{a}$ & $17.6(0.2) \mathrm{a}$ & $16.3(0.4) \mathrm{a}$ & $25.3(3.0) b$ & $36.7(2.1) b$ \\
\hline Week 7 manure & $35.8(3.1) b$ & $46.8(2.1) \mathrm{a}$ & $17.6(0.3) \mathrm{a}$ & $15.7(0.7) \mathrm{a}$ & $33.2(3.3) \mathrm{a}$ & $41.2(2.0) \mathrm{b}$ \\
\hline Week 8 manure & $33.0(2.3) \mathrm{b}$ & $39.7(4.4) \mathrm{b}$ & $16.2(0.2) \mathrm{a}$ & $17.4(0.3) \mathrm{a}$ & $30.8(2.5) \mathrm{a}$ & $34.7(4.7) \mathrm{b}$ \\
\hline Cow manure & $36.2(1.9) \mathrm{b}$ & $22.2(2.2) \mathrm{c}$ & - & $14.5(0.4) \mathrm{b}$ & $32.3(2.5) \mathrm{a}$ & $15.0(1.3) \mathrm{c}$ \\
\hline
\end{tabular}

Note: Pupae from cow manure and control diets were not weighed in Budapest. $n=$ six replicates for each medium/manure at Budapest and Gainesville, with 50 first-instar H. aenescens applied to each replicate. Means in each column followed by the same letter are not significantly different $(P=0.05$, Duncan's multiple range test [SAS Institute 1985]).

$1992)$ or powdered milk and granulated sugar (1:1) (Budapest). Eggs were collected in the standard manner by allowing $H$. aenescens females to oviposit on cloth-covered balls of larval medium used previously for larval development (Hogsette and Washington 1995). To obtain the first instars used in the bioassay, eggs were incubated inside a piece of folded paper towel. This was moistened and tucked into a slit made in a small (250-ml) container of manure (Budapest) (Farkas et al. 1998) or standard fly diet (Gainesville) (Hogsette and Washington 1995). Containers with eggs were maintained at the standard laboratory conditions listed above and eggs hatched in $\approx 24 \mathrm{~h}$.

Larval Media. Animals providing manure for this study were 1- to 8-wk-old Holstein calves housed in standard weaning pens, and lactating Holstein cows maintained under standard conditions. Calves and cows were fed standard weaning and production diets, respectively. Manure samples were collected within minutes of defecation from three or four calves in each of the eight age groups, and from four lactating cows from the milking herd. Like samples were pooled and maintained at $-20^{\circ} \mathrm{C}$ for at least $24 \mathrm{~h}$ to destroy the arthropods present therein; but samples were allowed to warm to room temperature just before use. Manure moisture content was calculated for the Gainesville samples by drying four 100-g samples of manure from each age group for $3 \mathrm{~h}$ at $103^{\circ} \mathrm{C}$, then reweighing and averaging weight differences.

Bioassay. Manure (100 g) from each calf age group and from the adult cows was measured into individual 250-ml plastic cups; and 50 newly hatched first-instar $H$. aenescens were added with a natural-bristle artist's brush (No.4) moistened slightly with water (Hogsette and Washington 1995). All cups were labeled and held at $30^{\circ} \mathrm{C}$. Each cup was weighed daily. A reduction in weight was assumed to be from loss of water, and the appropriate amount of water necessary to return each cup to its original weight ( $\pm 1 \%$ of total weight) was sprayed on top of the manure. This prevented the manure from crusting and allowed larvae better access to the manure surface.

Each manure type (eight calf manures and one cow manure) was replicated six times simultaneously. The medium for the six control replications was the standard Hydrotaea laboratory diet (Hogsette and Washington 1995). Dates of pupation were recorded by cup. Pupae from the calf manures (Budapest and Gainesville) and the cow manure and control treatments (Gainesville only) were weighed individually, but pupae from the cow manure and control treatments were not weighed in Budapest. Weighed pupae were transferred into containers labeled with treatment and replication number, and the number of eclosing adults was recorded daily.

Statistical Analysis. Data from both locations were subjected to analysis of variance using a completely randomized design and the following model statement: pupal number, pupal weight, or adult number $=$ manure type, location, and rep. Duncan multiple range test was used for separation of means (SAS Institute 1985). Unless otherwise stated, $P=0.05$.

\section{Results and Discussion}

Hydrotaea aenescens was able to develop successfully in all manures tested, including those from lactating adult dairy cows (Table 1 ). Moisture in manure from calves $1-8 \mathrm{wk}$ old was 41.7, 60.8, 41.3, 54.9, 62.2, $65.0,61.1$, and $62.2 \%$, respectively, and moisture in the cow manure and the control diet was 81.2 and $61.4 \%$, respectively. Analysis indicated significant differences between the Gainesville and Budapest data sets, i.e., in Gainesville, survival to the pupal stage was higher $($ mean $=38.9 \pm 1.6$ compared with mean $=27.0 \pm 2.0)$ $(F=31.79 ; \mathrm{df}=1,110 ; P=0.0001)$, pupae were heavier $($ mean $=16.5 \pm 0.2 \mathrm{mg}$ compared with mean $=$ $15.1 \pm 0.7 \mathrm{mg})(F=8.13 ; \mathrm{df}=1,98 ; P=0.0053)$, and adult survival was higher (mean $=34.4 \pm 1.7$ compared with mean $=24.4 \pm 1.9)(F=22.98 ; \mathrm{df}=1,110$; $P=0.0001)$. However, trends were similar except for those observed in manures from calves that were from 1 to 3 wk old.

In the Budapest trials, $H$. aenescens development was almost nonexistent in manure from 1-wk-old calves, and very low numerically by comparison in manure from calves from 2 to 3 wk old (Table 1 ). In Gainesville, development in manure from 1-wk-old 
calves was significantly lower than in all other manure tested with the exception of cow manure (Table 1). In the first few days after birth, calves pass the contents of the gut retained from the fetal period (the dark, sticky meconium) and a material that is more or less white in color and has the consistency of congealed lard. At first, attempts were made to increase the moisture content of this white colored material by adding measured amounts of water. However, this idea was abandoned because it would not mix with water. Thus, manure from 1-wk-old calves (and all of the others) was tested at the moisture levels at which it was collected. Manure from 1-wk-old calves looked like a poor substrate for fly development, and this was supported by our test results.

By the beginning of week 2, calves generally develop a pathogen-induced diarrhea, and dextrose and antibiotics are administered parenterally to combat it. At this time, the manure is yellowish brown in color and is extremely attractive to house flies. In Gainesville, we recorded the highest production of $H$. aenescens pupae and adults in manure from calves 2 and 3 wk old, but in Budapest this surge in development did not occur until calves were 4 wk old (Table 1 ). There was apparently some difference between the manures that caused the decreased development in Budapest, e.g., diet, drug therapy. After week 3, development remained above $60 \%$ in the manures collected from 4 to 8-wk-old calves (Table 1). These results demonstrate that $H$. aenescens can develop in calf manure.

Because $H$. aenescens is not usually found in high numbers on dairies, we were not certain that this fly would develop at all in dairy cow manure. However, production of pupae and adults did occur, and at a higher rate in the Budapest trials than in the Gainesville trials (Table 1). We are unable to explain this difference in production, but differences in animal feeds, e.g., roughages versus concentrates, can result in developmental differences in flies reared in the manure (Schmidt 1985). These results demonstrate that $H$. aenescens can develop in cow manure.

It is interesting that manure from calves or lactating cows seems to have little or no effect on pupal weight (Table 1). In Gainesville there was a numerical difference in mean pupal weights between those produced in calf manure and those produced in the adult cow manure. In Budapest, the few pupae produced in manure from 1-wk-old calves were significantly lighter than all others (Table 1). Pupae from most calf manure samples exceeded the $16 \mathrm{mg}$ pupal weights produced by Hogsette and Washington (1995) with artificial laboratory diets. Mean development times (Gainesville only) from first instar to the pupal stage were $16 \pm$ $3 \mathrm{~d}$ in calf manure, $22 \pm 3 \mathrm{~d}$ in cow manure, and $12 \pm$ $1.2 \mathrm{~d}$ in the laboratory diet (control). Development time was $8.6 \pm 1.5 \mathrm{~d}$ in the standard Hydrotaea diet (diet 5) (Hogsette and Washington 1995).

Thus, results indicate that $H$. aenescens was able to use bovine manure to develop to an expected stage and weight within an expected period. The next step is to determine whether development of this type can occur in the field. Fly management systems with bi- ological control components are not new to beef and dairy cattle production. However, the most commonly used biological control agent in these systems has been the parasitic wasp (Greene 1990, Geden et al. 1992, Hogsette 1999). Hydrotaea aenescens would provide an alternative or additional choice for incorporation in integrated fly management systems and would be particularly useful in house fly development sites around calf weaning areas. Although laboratory-reared $\mathrm{H}$. aenescens have been released and established on dairies (J.A.H., and R.R.C., unpublished data), additional research is still necessary to determine why bovine manure and other suitable habitats such as silage and spilled feed are not exploited by large native populations of $H$. aenescens.

\section{Acknowledgments}

We are very grateful to Naora Lockhart and Sarah Wren (USDA-ARS, Gainesville) and Mónika Gyurkovszky (Szent István University, Department of Parasitology and Zoology, Budapest) for their invaluable help in the laboratory studies.

\section{References Cited}

Axtell, R. C. 1986. Fly control in confined livestock and poultry production. Agricultural Division, Ciba-Geigy, Greensboro, NC.

Betke, P., Th. Hiepe, P. Müller, R. Ribbeck, H. Schultka, and H. Schumann. 1989. Biologische Bekampfung von Musca domestica mittels Ophyra aenescens in Schweineproduktionsanlagen. Mh. Vet. Med. 44: 842 844.

Farkas, R., and J. Jantyik. 1990. Laboratory studies on $H y$ drotaea aenescens (Wiedemann, 1830) as a predator of house fly larvae. Parasitol. Hung. 23: 103-108.

Farkas, R. and L. Papp. 1990. Hydrotaea (Ophyra) species as potential biocontrol agents against Musca domestica (Diptera) in Hungary, pp. 169-176. In D. A. Rutz and R. S. Patterson (eds.), Biocontrol of arthropods affecting livestock and poultry. Westview, Boulder, CO.

Farkas, R., J. A. Hogsette, and L. Börzsönyi. 1998. Development of Hydrotaea aenescens (Wiedemann) and Musca domestica L. (Diptera: Muscidae) in poultry and pig manure of different moisture content. Environ. Entomol. 27: 695-699.

Geden, C. J., D. A. Rutz, R. W. Miller, and D. C. Steinkraus. 1992. Suppression of house flies (Diptera: Muscidae) on New York and Maryland dairies using releases of Muscidifurax raptor (Hymenoptera: Pteromalidae) in an integrated management program. Environ. Entomol. 21: 1419-1426.

Geden, C. J., R. E. Stinner, and R. C. Axtell. 1988. Predation by predators of the house fly in poultry manure: effects of predator density, feeding history, interspecific interference, and field conditions. Environ. Entomol. 17: 320 329.

Greene, G. L. 1990. Biological control of filth flies in confined cattle feedlots using pteromalid parasites, pp. 2942. In D. A. Rutz and R. S. Patterson (eds.), Biocontrol of arthropods affecting livestock and poultry. Westview, Boulder, CO.

Hogsette, J. A. 1979. The evaluation of poultry pest management techniques in Florida poultry houses. Ph.D. dissertation, University of Florida, Gainesville. 
Hogsette, J. A. 1999. Management of ectoparasites with biological control organisms. Int. J. Parasitol. 29: 147-151.

Hogsette, J. A., and R. D. Jacobs. 1999. Failure of Hydrotaea aenescens, a larval predator of the house fly, Musca domestica L., to establish in wet poultry manure on a commercial farm in Florida, USA. Med. Vet. Entomol. 13: $349-354$.

Hogsette, J. A., and P. G. Koehler. 1992. Comparative toxicity of aqueous solutions of boric acid and polybor 3 to house flies (Diptera: Muscidae). J. Econ. Entomol. 85: 1209-1212.

Hogsette, J. A., and F. Washington. 1995. Quantitative mass production of Hydrotaea aenescens (Diptera; Muscidae). J. Econ. Entomol. 88: 1238-1242.

Jespersen, J. B. 1994. Ophyra aenescens for biological control of Musca domestica. Dan. Pest. Infest. Lab. Ann. Rep. 1993.

Miller, R. W. 1993. The influence of dairy operations on the urban fly problem, pp. 25-33. In G. D. Thomas and S. R. Skoda (eds.), Rural flies in the urban environment. North Central Regional Research Publication 335. University of Nebraska, Lincoln.

Müller, P., H. Schumann, P. Betke, H. Schultka, R. Ribbeck, and Th. Hiepe. 1981. Zur Bedeutung des Musca domestica-Antagonisten Ophyra aenescens (Diptera: Muscidae). I. Zum Auftreten von Ophyra aenescens in Anlagen der Tierproduktion. Angew. Parasitol. 22: 212-216.
Nolan, M. P., and J. B. Kissam. 1987. Nuisance potential of a dump fly, Ophyra aenescens (Diptera: Muscidae), breeding at poultry farms. Environ. Entomol. 16: 828 - 831.

Robertson, S. H., and D. A. Sanders. 1979. Species composition and seasonal distribution of the dipterous fauna inhabiting swine confinement housing in west Texas. Southwest. Entomol. 4: 89-95.

Ruszler, P. L. 1989. Fly farming for survival. Zootech. Int. November: $48-49$.

SAS Institute. 1985. SAS user's guide: statistics. SAS Institute, Cary, NC.

Schmidt, C. D. 1985. Production of horn flies in manure from cattle on three different diets. Southwest. Entomol. 10: $279-282$.

Sick, F. 1971. Ophyra aenescens (Wied.) (Diptera: Muscidae) neu für Norddeutschland. Faun.Okol. Mitt. 4: 21-22.

Stein, W., A. Gál, and H. Gerneth. 1977. Zum Auftreten von Ophyra aenescens (Wiedemann) (Diptera: Muscidae) in Deutschland. II. Vorkommen - Die praeimaginalen Stadien. Z. Angew. Zool. 64: 217-230 (in German).

Turner, E. C., and L. Carter. 1990. Mass rearing and introduction of Ophyra aenescens (Wiedemann) (Diptera: Muscidae) in high-rise caged layer houses to reduce house fly populations. J. Agric. Entomol. 7: 247-257. 2001

Received for publication 2 July 1999; accepted 3 December 